\title{
GROWTH AND ENZYMATIC RESPONSES OF PHYTOPATHOGENIC FUNGI TO GLUCOSE IN CULTURE MEDIA AND SOIL
}

\author{
Beatriz de Oliveira Costa ${ }^{1}$ Ely Nahas ${ }^{2 *}$ \\ ${ }^{1}$ Programa de Pós Graduação em Agronomia em Ciência do Solo, Universidade Estadual Paulista, Jaboticabal, SP, Brasil; \\ ${ }^{2}$ Departamento de Produção Vegetal, Universidade Estadual Paulista, Jaboticabal, SP, Brasil.
}

Submitted: February 09, 2010; Approved: August 15, 2011.

\begin{abstract}
The effect of inoculation of Aspergillus flavus, Fusarium verticillioides, and Penicillium sp. in Dystrophic Red Latosol (DRL) and Eutroferric Red Latosol (ERL) soils with or without glucose on the total carbohydrate content and the dehydrogenase and amylase activities was studied. The fungal growth and spore production in culture medium with and without glucose were also evaluated. A completely randomized design with factorial arrangement was used. The addition of glucose in the culture medium increased the growth rate of A. flavus and Penicillium sp. but not of F. verticillioides. The number of spores increased 1.2 for F. verticillioides and 8.2 times for A. flavus in the medium with glucose, but was reduced 3.5 times for Penicillium sp. The total carbohydrates contents reduced significantly according to first and second degree equations. The consumption of total carbohydrates by A. flavus and Penicillium sp. was higher than the control or soil inoculated with $F$. verticillioides. The addition of glucose to soils benefited the use of carbohydrates, probably due to the stimulation of fungal growth. Dehydrogenase activity increased between 1.5 to 1.8 times $(p<0.05)$ in soils with glucose and inoculated with the fungi (except $F$. verticillioides), in relation to soil without glucose. Amylase activity increased 1.3 to 1.5 times due to the addition of glucose in the soil. Increased amylase activity was observed in the DRL soil with glucose and inoculated with A. flavus and Penicillium sp. when compared to control.
\end{abstract}

Key words: Fusarium verticillioides, Aspergillus flavus, Penicillium sp., dehydrogenase, amylase.

\section{INTRODUCTION}

Fungi are found in many soils and comprise an important part of the microbial population, performing many biochemical processes that transform organic matter and nutrients $(17,23$, 25). Therefore, environmental conditions can have a decisive influence on fungi growth, and species more adapted to the organic matter degradation can overwhelm other species that depend on parasitism for their survival. The competition for nutrients and space has been used to control pathogenic fungi in soil $(3,30,34)$. However, the addition of organic matter in soil as green manure did not reduce the population of the fungus Pythium even with increased populations of microorganisms (21).

\footnotetext{
*Corresponding Author. Mailing address: Departamento de Produção Vegetal, Faculdade de Ciências Agrárias e Veterinárias, UNESP, Rod. Prof. Paulo Donato Castellane s/n, 14884-900 Jaboticabal, SP, Brazil.; Tel. +55 16 3209-2652/2653.; E-mail: enahas@ fcav.unesp.br
} 
For growth, fungi require different nutrients at different concentrations. In soil, the natural habitat of these fungi, the availability of these nutrients in various ecological conditions, including physical and chemical factors, can influence growth and activity $(2,15,28)$. The search for nutrients depends on the metabolic ability of each fungal species. Due to this competition, saprophytic species of microorganisms are forced to survive by changing to a parasitic state. Thus, many fungal diseases in plants have caused considerable losses in agriculture, especially species of genera Fusarium, Aspergillus, and Penicillium (25, 27, 31). For example, the return of crop residues in soil increased the size and changes the composition of the Fusarium community (35).

Based on the utilization patterns of 24 carbon sources, including sugars, amino acids, and fatty acids, concluded that $A$. flavus and $F$. verticillioides occupied different ecological niches, which explains the nutritional dominance of fungal species under different environmental conditions (15). Sugars are found in soil and the glucose is used by most fungi as a source of carbon and energy. Several authors have reported that the genera Fusarium, Aspergillus, and Penicillium use glucose in different metabolic processes $(6,12,22,24)$. For example, macroconidia germination of $F$. graminearum only occurred when incubated in medium with glucose or sucrose, but not in deionized water (6). Higher levels of intermediate compounds in the three carboxylic acids were produced when $F$. oxysporum was grown in a mixture of acetate and glucose, compared to growth only with glucose (24).

Soil fungi secrete several enzymes used in cycling and uptake of nutrients. Synthesis of these enzymes depends on environmental conditions as well as the ability of each species and fungus strain. Of 115 cultures isolated from different sources such as soil, air, and infected plants, 68\% had the ability to degrade cellulose. Fungi isolated from root nodules of fava, such as Cladosporium cladosporioides, Fusarium moniliforme, $F$. oxysporum, $F$. solani, Macrophominia phaseolina, and Rhizoctonia solani, have shown cellulase, pectin lyase, polygalacturonase, protease, urease, amidase, acid phosphatase, alkaline phosphatase, and arylsulfatase enzymes activities (23). The fungi A. niger, A. fumigatus, A. flavus, and Penicillium frequestans, isolated from agricultural waste, were used for $\alpha$-amylase production (1). Dehydrogenase activity and functional diversity of microorganisms decreased in the greenhouse compared to soils under rice-wheat rotation in open fields (20).

This study describes the effect of inoculation of three filamentous fungi namely Aspergillus flavus, Fusarium verticillioides, and Penicillium sp. on total carbohydrates content as well as dehydrogenase and amylase activities using two soil types (with or without glucose).

\section{MATERIAL AND METHODS}

\section{Soil sampling}

Soils were collected at the $0-15 \mathrm{~cm}$ depth after the summer crops in March 2008 from two areas located at UNESP/Jaboticabal. The soils used were Eutroferric Red Latosol with native forest and Dystrophic Red Latosol with an annual crop of corn or soybeans. Soils were air dried and sifted through sieve with a $4 \mathrm{~mm}$ mesh.

\section{Fungi: collection and cultivation}

The fungi Fusarium verticillioides, Aspergillus flavus, and Penicillium sp. were isolated from maize seeds (Zea mays), identified according to Barnett and Hunter (5), and grown in the potato dextrose agar medium supplemented with yeast extract.

\section{Influence of glucose in culture medium on mycelial growth and spore production}

Fungi were point inoculated on the center of Petri dishes with Sabouraud agar medium, with and without glucose, to determine the diameter of the colonies and count the number of spores, then incubated at $30^{\circ} \mathrm{C}$ for 10 days. After this period, 
$10 \mathrm{ml}$ of Tween $0.1 \%(\mathrm{w} / \mathrm{v})$ were added to each plate for spore harvest. The spore numbers were counted in a Neubauer camera.

\section{Preparation of soils}

In each Petri dish (9 $\mathrm{cm}$ diameter), $62 \mathrm{~g}$ of the soils were added. A volume of distilled water was added corresponding to $60 \%$ of the water retention capacity for each soil. For each gram of soil, $1 \times 10^{6}$ fungi spores and $1 \%$ glucose (when determined) were added with the water of rehydration. These soils were incubated for up to 21 days at $25^{\circ} \mathrm{C}$.

\section{Determination of total carbohydrates and dehydrogenase and amylase activities}

The carbohydrate content was determined after soils incubation for 5, 13, and 21 days based in Angers and Mehuys (4) in a hot extract obtained by $\mathrm{H}_{2} \mathrm{SO}_{4} 1.5 \mathrm{~mol} \mathrm{~L}^{-1}$. The dehydrogenase activity was determined after 13 days incubation by mixing $3 \mathrm{~g}$ soil with $0.03 \mathrm{~g} \mathrm{CaCO}_{3}$ and $0.5 \mathrm{ml}$ of tetrazolium chloride solution (TTC) $3 \%$ at $37^{\circ} \mathrm{C}$ for 24 hours (10). The reaction mixture was filtered on Whatman No. 1 filter paper, the triphenyl formazan (TPF) was extracted with $20 \mathrm{~mL}$ methanol, and spectrofotometrically measured at 485 $\mathrm{nm}$, using methanol as a control. Enzyme activity was expressed as $\mu \mathrm{g}$ TPF $\mathrm{g}^{-1}$ dry soil $24 \mathrm{~h}^{-1}$. Amylase activity was determined after 13 days of incubation by mixing $2 \mathrm{~g}$ soil with $0.3 \mathrm{ml}$ of toluene and $5 \mathrm{ml} 0.1 \mathrm{M}$ acetate buffer $\mathrm{pH} 5$, containing $50 \mathrm{mg}$ soluble starch at $37^{\circ} \mathrm{C}$ for $24 \mathrm{~h}$ (11). The slurry was then filtered through a Whatman No. 1 filter paper.

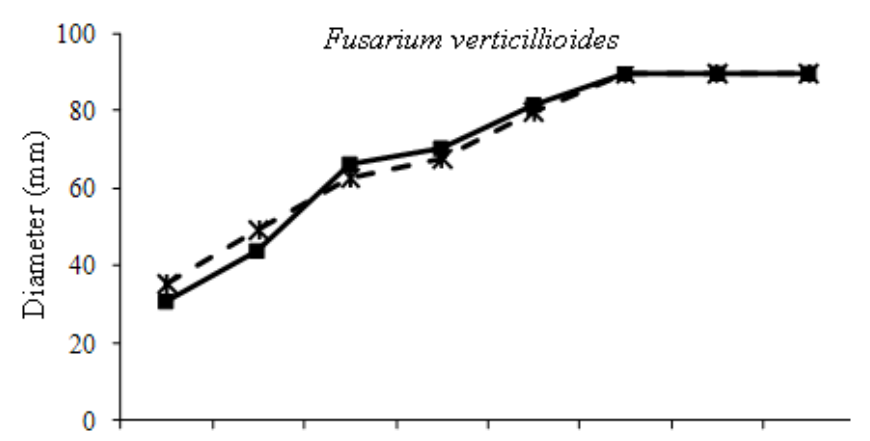

Reducing sugar analyses on the filtered was done by the method of Somogyi (32). Results were expressed as $\mu$ g glucose $\mathrm{g}^{-1}$ dry soil $24 \mathrm{~h}^{-1}$.

\section{Statistical analysis}

All results reported are averages of triplicate determinations. Data of amylase and dehydrogenase activities was performed in a completely randomized design and using the ANOVA program of the Statistical Analysis Systems (29). Tukey's estimates of least significant differences were calculated from the ANOVA analysis. Regression equations and coefficients of determination $\left(\mathrm{R}^{2}\right)$ for relationship between carbohydrate contents and time of incubation were determined.

\section{RESULTS AND DISCUSSION}

Effect of the addition of glucose on radial growth and the spores count

The radial growth of the fungi increased linearly and reached a maximum in 7-8 days. While A. flavus and $F$. verticillioides growth were limited by the plate size, for Penicillium sp. radial growth reached only $27 \mathrm{~mm}$ and then had a stationary phase (Figure 1). This fungus is known to have lower radial growth rates as found in $P$. chrysogenum in relation to other fungi species (33). In most fungi, glucose plays a central role in metabolism (9). This glucose dependence was demonstrated for the fungi A. flavus and Penicillium sp., which had their growth restricted in the absence of glucose by about 44 and $21 \%$ respectively, but not for $F$. verticillioides.

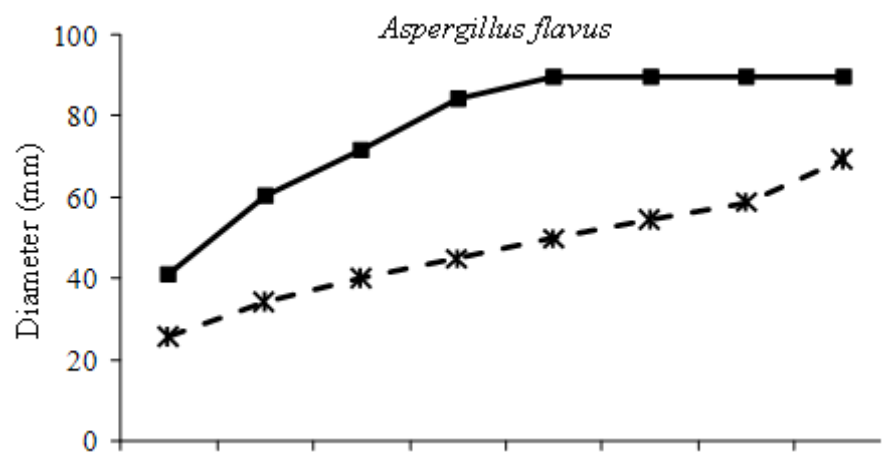




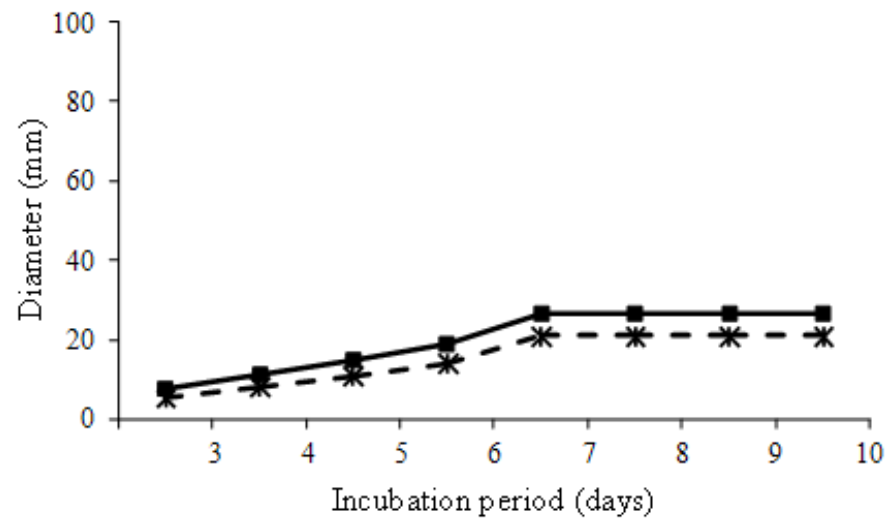

The number of spores increased 1.2 in F. verticillioides and 8.2 times in A. flavus, but was reduced 3.5 times in Penicillium sp., when comparing the cultures in the presence and absence of glucose (Figure 2). Spore production can occur during the decline of mycelial growth due to the lack of nutrients or the result of the accumulation of toxic substances from fungal metabolism (9). Glucose depletion seems to be the factor for Piriformospora indica sporulation (18). In the conditions of this work, there was no possibility that the fungus consume all the glucose added to the medium when inoculated with A. flavus. Therefore, other factors may have influenced
Figure 1. Radial growth of fungi in culture medium with (-匹-) or without ( $*$-) glucose.

sporulation. The small increase in the number of spores for $F$. verticillioides compared with A. flavus is because the growth of $F$. verticillioides was not dependent on the addition of glucose in the culture medium. However, the absence of glucose stimulated an increase in the number of spores in Penicillium sp. possibly due to nutritive stress. Calvo et al. (8) showed that growth and spore production by A. flavus are stimulated in culture medium containing simple sugars such as glucose, fructose, sucrose, and sorbitol as the unique carbon source; however, the conditions for Penicillium sp. growth were different from those used in this study.

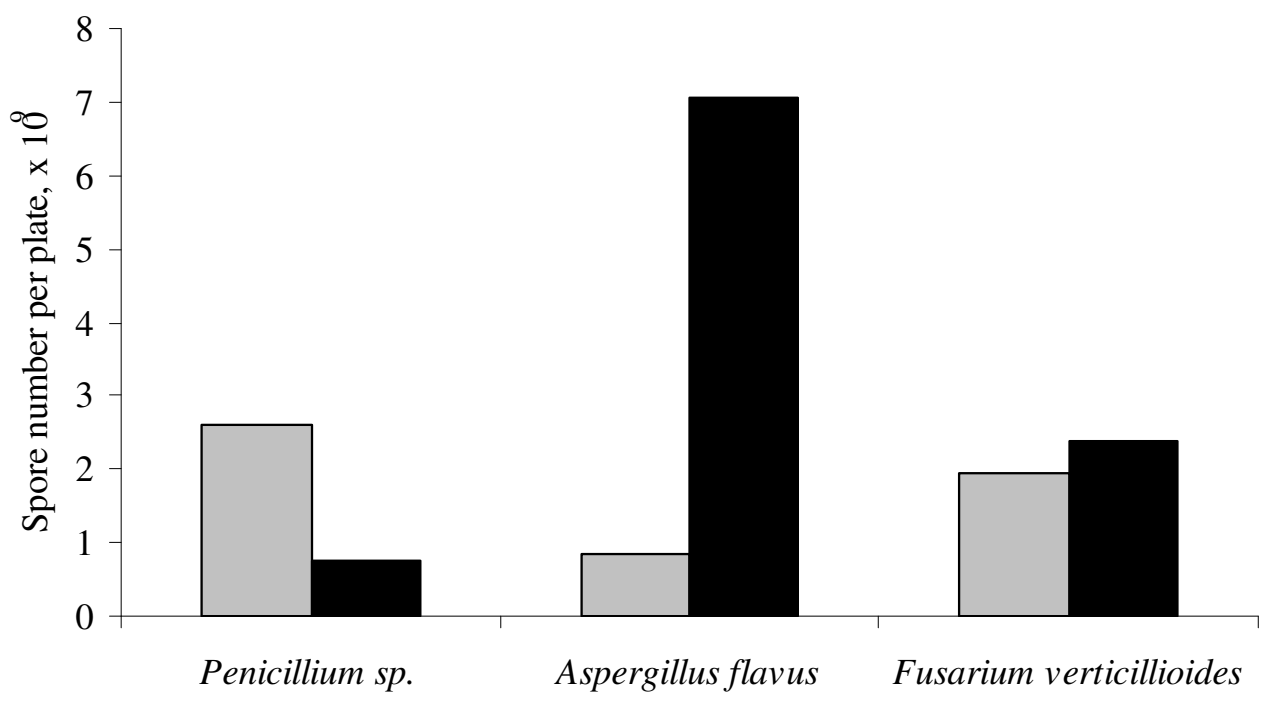

Figure 2. Spores produced by fungi grown in culture medium, with $(\boldsymbol{\square})$ or $(\square)$ without glucose. 


\section{Total carbohydrates content}

The amount of total carbohydrates found after fungal growth in soil for up to 21 days mostly decreased (Figure 3). A larger content of carbohydrates was found in the ERL soil than DRL soil. As expected, the addition of glucose increased the amounts of total carbohydrates. Carbohydrate content decreased at the end in relation to the start of the incubation period from 20 to $83 \%$ when Penicillium sp. was inoculated in the soil, 18 to $79 \%$ with A. flavus, 0 to $85 \%$ with $F$. verticillioides, and 16 to $69 \%$ in the non-inoculated soil (Figure 3). This is consistent with previous studies which reported that the decrease of carbohydrates contents can be related to microbial activity (19). The reduction of the total carbohydrate content was significantly adjusted to first and second degree equations (Table 1). Responses were not significant in non- inoculated soil or soil inoculated with $F$. verticillioides. In general, the variation of carbohydrate content adjusted to first degree equations when glucose was added to the soil.

In the ERL soil inoculated with $F$. verticillioides, no change in the carbohydrate quantities was observed, which is consistent with glucose having no effect on fungal growth in culture medium. In fact, the considerable decrease in the amount of carbohydrates, observed in the DRL soil with glucose and inoculated by $F$. verticillioides, can be attributed to other microorganisms in the soil. In the ERL and DRL soils inoculated with A. flavus and Penicillium sp., the consumption of carbohydrates was more pronounced in soils with glucose than in soils without glucose (Figure 3). This result suggests that the addition of glucose may have stimulated the growth of A. flavus and Penicillium sp.

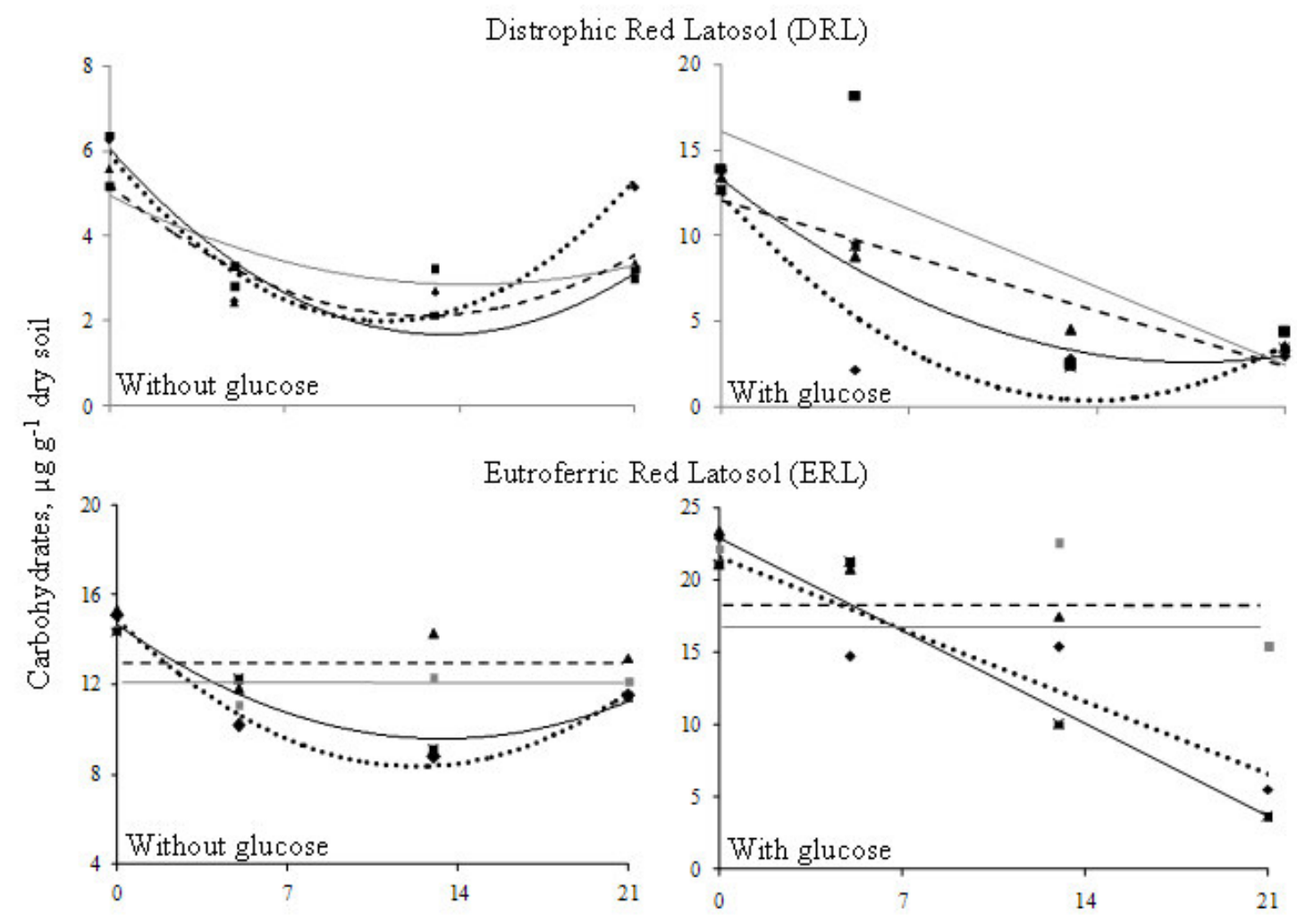

Incubation period (days)

Figure 3. Contents of total carbohydrates in soil after fungi inoculation.

Aspergillus flavus (. . . .), Fusarium verticillioides (- $\mathbf{\Delta}$-), Penicillium sp. (一- -), non-inoculated soil (- $\square-)$. 
Table 1. Regression equations and coefficients of determination $\left(\mathrm{R}^{2}\right)$ for relationship between total carbohydrates amounts and time of incubation in soils, with or without glucose.

\begin{tabular}{|c|c|c|c|c|}
\hline Glucose & Inoculation & $\begin{array}{ll}\text { Equations } \\
\end{array}$ & $\mathbf{R}^{2}$ & F test $^{(1)}$ \\
\hline \multirow{5}{*}{ Without } & & Distrophic Red Latosol (DRL) & & \\
\hline & Without inoculation & $y=4959-291.1 x+10.2 x^{2}$ & 0.86 & $7.35 * *$ \\
\hline & A. flavus & $y=5933-718.4 x+32.8 x^{2}$ & 0.91 & $76.71^{* *}$ \\
\hline & F. verticillioides & $y=5213-494.2 x+19.7 x^{2}$ & 0.80 & $27.81^{* *}$ \\
\hline & Pennicilium sp. & $y=6080-659.5 x+24.7 x^{2}$ & 0.94 & $43.53^{* *}$ \\
\hline \multirow{4}{*}{ With } & Without inoculation & $y=16072-648.8 x$ & 0.62 & $51.91 * *$ \\
\hline & A. flavus & $y=12413-1739.0 x+63.0 x^{2}$ & 0.81 & $16.83^{* *}$ \\
\hline & F. verticillioides & $y=12090-463.1 x$ & 0.89 & $26.45^{* *}$ \\
\hline & Pennicilium sp. & $\mathrm{y}=13272.5-1208.0 \mathrm{x}+34.40 \mathrm{x}^{2}$ & 0.96 & $5.00 * *$ \\
\hline \multirow{5}{*}{ Without } & & Eutroferric Red Latosol (ERL) & & \\
\hline & Without inoculation & $y=12.5$ & - & - \\
\hline & A. flavus & $y=14882-1059.0 x+43.18 x^{2}$ & 0.98 & $16.69^{* *}$ \\
\hline & F. verticillioides & $y=13.7$ & - & - \\
\hline & Pennicilium sp. & $y=14676-764.3 x+28.67 x^{2}$ & 0.94 & $7.36 * *$ \\
\hline \multirow{4}{*}{ With } & Without inoculation & $y=20.3$ & - & - \\
\hline & A. flavus & $y=21555-711.4 x$ & 0.84 & $13.90 * *$ \\
\hline & F. verticillioides & $y=22.1$ & - & - \\
\hline & Pennicilium sp. & $y=22878-915.2 x$ & 0.94 & $23.01 * *$ \\
\hline
\end{tabular}

(1): $* *=$ significant at $1 \% . \mathrm{y}=$ total carbohydrate content in soil $\left(\mu \mathrm{g} \mathrm{g}^{-1}\right.$ dry soil), $\mathrm{x}=$ incubation period (days).

\section{Dehydrogenase activity}

Except in the soil inoculated with $F$. verticillioides, the dehydrogenase activity increased 1.5 to 1.8 times $(p<0.05)$ in soil with glucose in relation to soil without glucose. Dehydrogenase activity was 1.7 to 2.0 times higher in the ERL compared to DRL soil (Figure 4). DRL soil without glucose and inoculated with A. flavus and Penicillium sp. had higher dehydrogenase activity than the other soils. Dehydrogenase is an indication of oxidative metabolism (7), of intracellular nature, and is linked to viable cells. The increase in dehydrogenase activity was related to the microbial population growth in soil $(16,26)$. Therefore, the increase in dehydrogenase activity was probably due to the growth of microorganisms, especially the fungi inoculated in soil. The enzyme activity was stimulated in all soils with glucose and inoculated with the fungi, except $F$. verticillioides (Figure 4). This effect was observed by Casida (10), who found increased activity in the soil with added glucose when compared to the control.

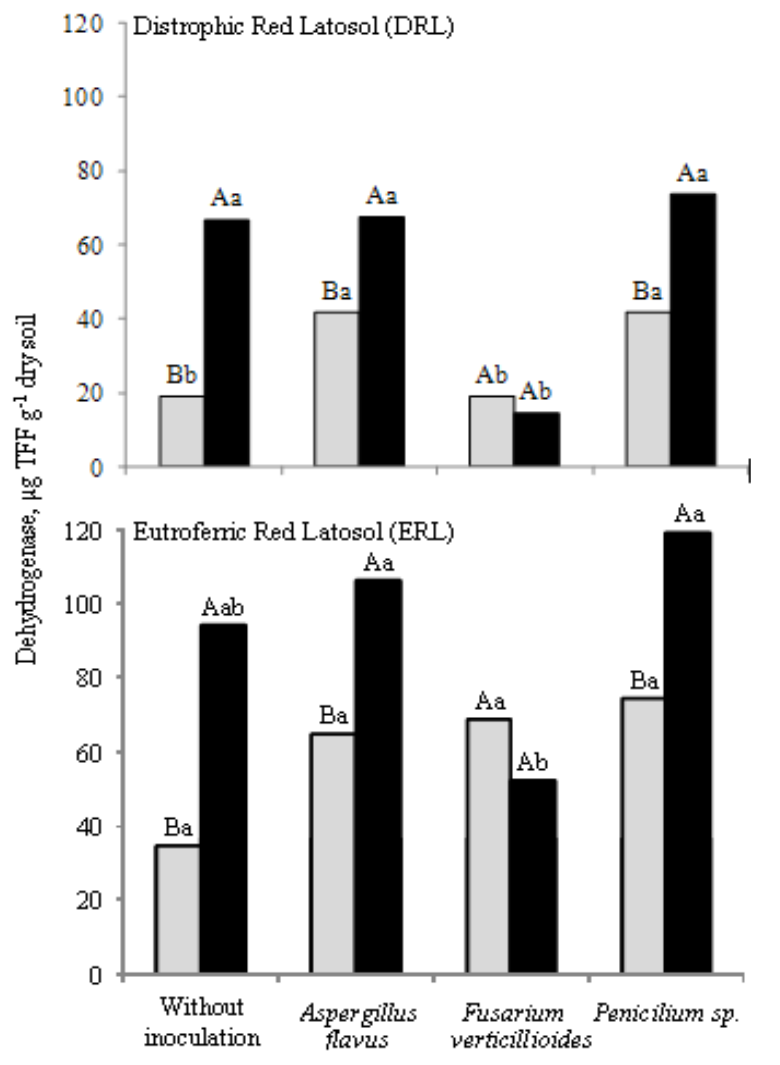

Figure 4. Dehydrogenase activity found in the soils after fungi inoculation. Column with the same capital (compare with and without glucose) and lower letter (comparison of fungi) do not differ by Tukey test at 5\%; ( $\boldsymbol{\square})$ with and $(\square)$ without glucose. 


\section{Amylase activity}

The same trend was observed with respect to amylase activity that increased 1.3 to 1.5 times in the soil with glucose in relation to the soil without glucose and 1.3 to 1.4 times when compared ERL with DRL soil, respectively (Figure 5). However, the stimulation of amylase activity due to the addition of glucose was not observed in all soils (Figure 5). There was no difference in the amylase activity when noninoculated soils with glucose were compared to soils without glucose. Amylase activity increased significantly in DRL soil with glucose added and inoculated with A. flavus and Penicillium sp. in relation to other treatments and in the inoculated ERL soil when compared to the non-inoculated soil. Amylolytics fungi were found in the soil (28). $F$. verticillioides, A. flavus, and Penicillium sp. produced amylase in different culture media $(13,14)$. Glucose stimulated amylase activity in the medium inoculated with A. fumigatus when compared to control (13). Therefore, these results explain the increased amylase activity in soil containing glucose found in our work.

In conclusion, the fungus reached the maximum growth in culture medium after 7-8 days. The growth of Penicillium sp. was limited when compared with $A$. flavus and $F$. verticillioides. The addition of glucose in the culture medium increased the growth rate of A. flavus and Penicillium sp. but not $F$. verticillioides. The number of spores produced by Penicillium sp. was increased in the culture medium without glucose and the other fungi in medium with glucose. These responses probably affected the development of the fungi in the soil. The carbohydrate content of the soil was reduced from 16 to $85 \%$ due to fungi growth, which resulted in an increase of 1.5 to 2.0 times in the dehydrogenase activity and 1.3 to 1.5 times in the amylase activity. The relevance of these results can be inferred by the potential answers about what factors influence the growth of pathogenic fungi in the soil and the possibility of plant infection.

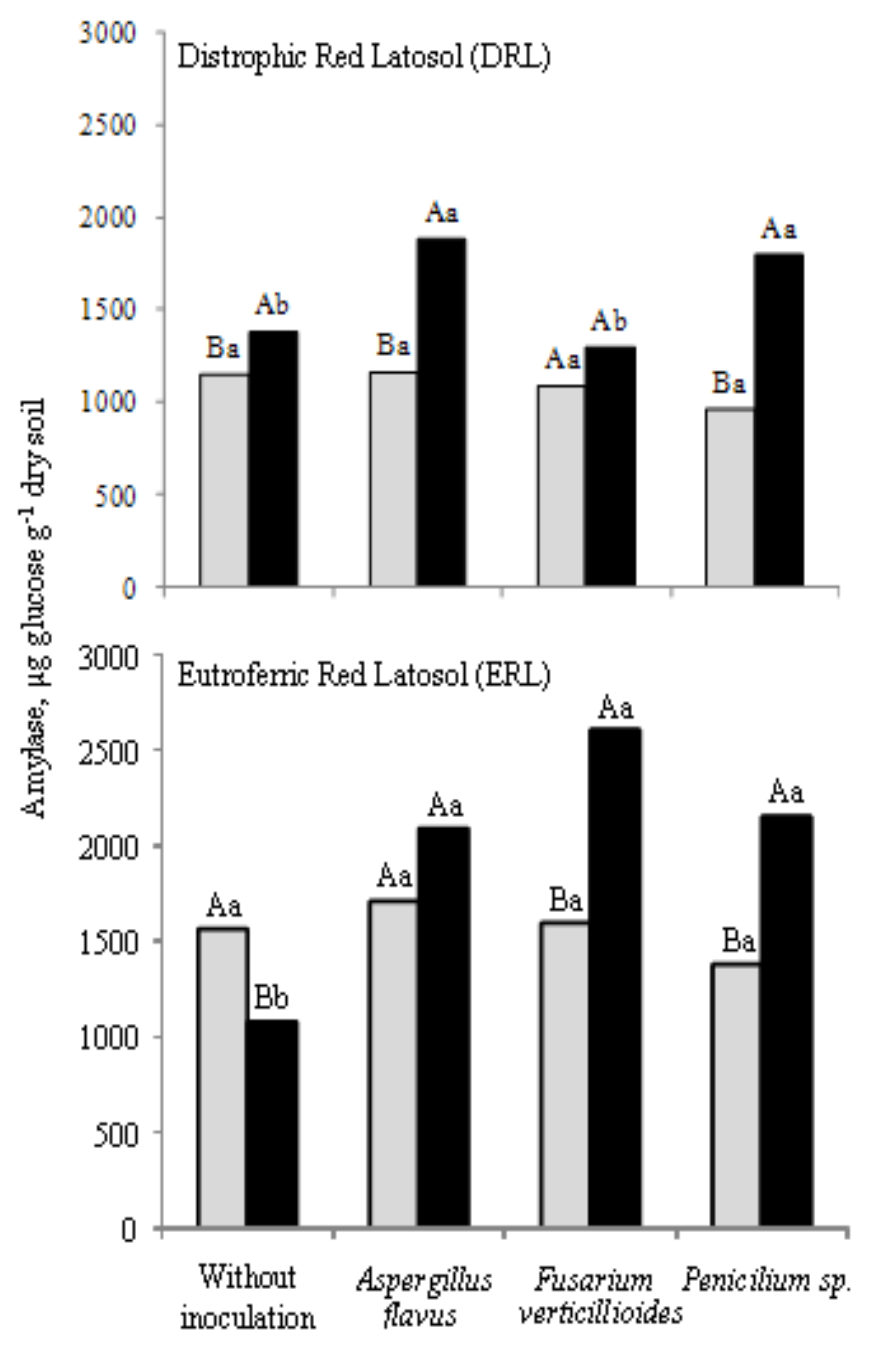

Figure 5. Amylase activity found in the soils after fungi inoculation. Column with the same capital letter (compare with and without glucose) and lower (comparison of fungi) do not differ by Tukey test at 5\%; ( $\square$ ) with and ( $\square$ ) without glucose.

\section{REFERENCES}

1. Adeniran, A.H.; Abiose, S.H. (2009). Amylolytic potentiality of fungi isolated from some Nigerian agricultural wastes. Afr. J. Biotechnol., v.8, p.667-672.

2. Almeida, A.P.; Corrêa, B.; Mallozzi, M.A.B.; Sawazaki, E.; Soares, L.M.V. (2000). Mycoflora and aflatoxin/fumonisin production by fungal isolates from freshly harvested corn hybrids. Braz. J. Microbiol., v.31, p.321-326. 
3. Ambrósio, M.M.Q.; Bueno, C.J.; Padovanni, C.R.; Souza, N.L. (2009). Sobrevivência de fungos fitopatogênicos habitantes do solo, em microcosmo, simulando solarização com prévia incorporação de materiais orgânicos. Summa Phytopathol., v.35, p.20-25.

4. Angers, D.A.; Mehuys, G.R. (1989). Effects of cropping on carbohydrate content and water-stable aggregation of a clay soil. Can. J. Soil Sci., v.69, p.373-380.

5. Barnett, H. L.; Hunter, B. B. (1998). Illustrated genera of imperfect fungi. St. Paul, Minnesota, APS Press, 218p.

6. Beyer, M.; Röding, S.; Ludewig, A.; Verreet, J.A. (2004). Germination and survival of Fusarium graminearum macroconidia as affected by environmental factors. J. Phytopathol., v.152, p.92-97.

7. Buzinaro, T.N.; Barbosa, J.C.; Nahas E. (2009). Atividade microbiana do solo em pomar de laranja em resposta ao cultivo de adubos verdes. Rev. Bras. Frutic., v.31, p.408-414.

8. Calvo, A.M.; Wilson, R.A.; Bok, J.W.; Keller, N.P. (2002). Relationship between secondary metabolism and fungal development. Microbiol. Mol. Biol. Rev., p.447-459.

9. Carlile, M.J.; Watkinson, S.C.; Gooday, G.W. (2001). The Fungi. London: Academic Press, 588p.

10. Casida, L.E.; Klein, D.A.; Santoro, T. (1964). Soil dehydrogenase activity. Soil Sci., v. 98, p.371-376.

11. Cole, M.A. (1977). Lead inhibition of enzyme synthesis in soil. Appl. Environ. Microbiol., v.33, p.262-268.

12. Daynes, C.M.; McGee, P.A.; Midgley, D.J. (2008). Utilisation of plant cell-wall polysaccharides and organic phosphorus substrates by isolates of Aspergillus and Penicillium isolated from soil. F. Ecol., v.1, p.94-98.

13. Domingues, C.M.; Peralta, R.M. (1993). Production of amylase by soi fungi and partial biochemical characterization of amylase of a selected strain (Aspergillus fumigatus fresenius). Can. J. Microbiol., v.39, p.681685.

14. Figueira, E.L.Z.; Hirooka, E.Y. (2000). Culture medium for amylase production by toxigenic fungi. Braz. Arch. Biol. Technol., v.43, p.461467.

15. Giorni, P.; Magan, N.; Battilani, P. (2009). Environmental factors modify carbon nutritional patterns and niche overlap between Aspergillus flavus and Fusarium verticillioides strains from maize. Int. J. Food. Microbiol., v.130, p.213-218.

16. Gréggio, T.C.; Nahas, E. (2007). Atividade enzimática do solo sob dois fragmentos florestais. Cient., v.35, p.179-187.

17. Guimarães, L.H.S.; Nogueira, S.C. P.; Michelin, M.; Rizzatti, A.C.S.; Sandrim, V.C.; Zanoelo, F.F.; Aquino, A.C.M.M.; Junior, A.B.; Polizeli, M.L.T.M. (2006) Screening of filamentous fungi for production of enzymes of biotechnological interest. Braz. J. of Microbiol., v.37, p.474480 .

18. Kumar,V.; Sahai, V.; Bisaria, V.S. (2011). High-density spore production of Piriformospora indica, a plant growth-promoting endophyte, by optimization of nutritional and cultural parameters. Biores. Technol., v.102, p. 3169-3175.

19. Kuo, S.; Sainju, U.M.; Jellum, E.J. (1997). Winter cover crop effects on soil organic carbon and carbohydate in soil. Soil Sci. Soc. Am. J,. v.61, p.145-152.

20. Lin, X.G.; Yin, R.; Zhang, H.Y.; Huang, J.F.; Chen, R.R.; Cao, Z.H. (2004). Changes of soil microbiological properties caused by land use changing from rice-wheat rotation to vegetable cultivation. Environ. Geochem. Health., v.26, p.119-128.

21. Manici, L.M.; Caputo, F.; Babini, B. (2004). Effect of green manure on Pythium spp. population and microbial communities in intensive cropping systems. Plant Soil, v.263, p. 133-142.

22. Olsson, G.; Pott, B.M.; Larsson, L.; Holst, O.; Karlsson, H.T. (1994). Microbial desulfurization of coal by Thiobacillus ferrooxidans and thermophilic archaea. Fuel Process. Technol., v.40, p.277-282.

23. Omar, S.A.; Abd-Alla, M.H. (2000). Physiological aspects of fungi isolated from root nodules of faba bean (Vicia faba L.). Microbiol. Res., v.154, p.339-347.

24. Panagiotou, G.; Pachidou, F.; Petroutsos, D.; Olsson, L.; Christakopoulos, Paul. (2008). Fermentation characteristics of Fusarium oxysporum grown on acetate. Biores. Technol., v.99, p.7397-7401.

25. Prade, C.A.; Matsumura, A.T.; Ott, A.P.; Porto, M.L. (2007). Diversidade de fungos do solo em sistemas agroflorestais de Citrus com diferentes tipos de manejo no município de Roca Sales, Rio Grande do Sul, Biociências, v.15, p.73-81.

26. Ralte, V.; Pandey, H.N.; Barik, S.K.; Tripathi, R.S.; Prabhu, S.D. (2005) Changes in microbial biomass and activity in relation to shifting cultivation and horticultural practices in subtropical evergreen forest ecosystem of north-east India. Acta Oecol., v.28, p.163-172.

27. Rocha, L.O.; Soares, M.M.S.R.; Corrêa, C.L. (2004). Análise da contaminação fúngica em mostras de Cassia acutifolia Delile (sene) e Peumus boldus (Molina) Lyons (boldo-do-Chile) comercializadas na cidade de Campinas, Brasil. Rev. Bras. Cienc. Farm., v.40, p.521-527.

28. Sanomiya, L.T.; Nahas, E. (2003). Microrganismos produtores de hidrolases envolvidos nas transformações dos compostos do carbono e do nitrogênio do solo. Cienc. Rural, v.33, p.835-842.

29. SAS Institute (1990) Statistical Analysis System, SAS/STAT user's guide (Version 6). 3rd ed. (Cary: NC).

30. Silva, E.A.A.; Von Pinho, E..V.R.; Vieira, M.G.G.C.; Carvalho, M.L.M.; Machado, J.C. (2000). Alterações dos padrões de isoenzimas em sementes de milho infectadas por fungos. Pesq. Agropec. Bras., v.35, p.1725-1732.

31. Silva, L.R.C.; Souza, O.C.; Fernades, M.J.S.; Lima, D.M.M.; Coelho, R.R.R.; Souza-Motta, C.M. (2011). Culturable fungal diversity of shrimp litopenaeus vannamei boone from breeding farms in Brazil. Braz. J. Microbiol., v. 42, p.49-56.

32. Somogyi, M. (1952). Notes on sugar determination. J. Biol. Chem., 
v.195, p.19-23.

33. Trinci, A.P.J. (1971). A kinetic study of the growth of Aspergillus nidulans and other fungi. J. Gen. Microbiol., v.57, p.11-24.

34. Vinale, F.; Sivasithamparam, K.; Ghisalberti, E.L.; Marra, R.; Woo, S.L.; Lorito, M. (2008). Trichoderma-plant pathogen interactions. Soil Biol.
Biochem., v.40, p.1-10.

35. Wakelin, S.A.; Warrenb, R.A.; Kongc, L.; Harveyb, P.R. (2008). Management factors affecting size and structure of soil Fusarium communities under irrigated maize in Australia. Appl. Soil Ecol., v.39, p.201-209.

\section{$(\mathrm{cc}) \mathbf{B Y - N C}$}

All the content of the journal, except where otherwise noted, is licensed under a Creative Commons License 